\title{
ANALISA PENGARUH GAYA ELEKTROSTATIK PADA SPEKTRUM PENCITRAAN RESONANSI MAGNETIK (MRI) DALAM JARINGAN BIOLOGI
}

\author{
Salomo, Nova Lestari", Muhammad Hamdi \\ Program Studi S1 Fisika FMIPA, Universitas Riau \\ *E-mail korespondensi: Novalestari180@gmail.com
}

\begin{abstract}
A study of magnetic core resonance imaging modeling of biological tissue has been carried out in analyzing the effect of electrostatic forces with computational approach. This analysis aims to look at the effect of electric and magnetic force on the spectrum of breast cancer tissue. Physical parameters were determined using the modeled wave equation with the application of mathematical wolfram software 9. Computational or modeling results obtained 6 variations of the MRI spectrum showing the peak magnitude of the electric and magnetic spectrum changes by varying the resolution and distance. This is evidenced from the maximum resolution range i.e. the peak of the electric field spectrum at amplitude 25 a.u is at a concentration of 5 ppm. Resolution of spectrum peak medium is at concentration of 3-4 ppm whereas minimum resolution has 4 peak spectrum that is at concentration 1-2 ppm, 2-3ppm, 3-4ppm and 4ppm. the result of MRI spectrum for distance variation resulted in spectrum change, further reduced the distance then the mri spectrum in magnetic and electric field approaching spin 1 .
\end{abstract}

Keywords: Modeling, electrostatic force, radio frequency and MRI

\begin{abstract}
ABSTRAK
Telah dilakukan penelitian tentang pemodelan pencitraan resonansi magnetic inti pada jaringan biologi dalam menganalisa pengaruh gaya elektrostatik dengan pendekatan komputasi. Analisa ini bertujuan untuk melihat pengaruh gaya medan listrik dan magnet pada spectrum jaringan kanker payudara. Parameter- parameter fisis ditentukan menggunakan persamaan gelombang dimodelkan dengan aplikasi perangkat lunak wolfram matematika 9. Hasil komputasi atau pemodelan diperoleh 6 variasi spektrum MRI yang menunjukkan adanya perubahan puncak spectrum gaya listrik dan magnet dengan melakukan variasi resolusi dan jarak. Hal ini dibuktikan dari ketegori resolusi maksimum yaitu puncak spectrum medan listrik pada amplitudo 25 a.u berada pada konsentrasi 5 ppm. Resolusi medium puncak spectrum berada di konsentrasi 3-4 ppm sedangkan resolusi minimum memiliki 4 puncak spectrum yaitu berada pada konsentrasi 1-2 ppm, 2-3ppm, 3-4ppm dan 4ppm. Hasil spketrum MRI untuk variasi jarak menghasilkan perubahan spektrum, semakin diperkecil jarak maka spektrum MRI pada medan magnet dan medan listrik mendekati spin 1.
\end{abstract}

Kata kunci: Pemodelan, gaya elektrostatik, frekuensi radio dan MRI.

\section{PENDAHULUAN}

Radiasi elektromagnetik tidak memiliki massa, tidak berpengaruh oleh medan listrik dan medan magnet dan memiliki kecepatan konstan dalam satu medium. Radiasi elektromagnetik yang digunakan dalam pencitraan diagnostik salah satunya ialah frekuensi radio. Frekuensi radio merupakan bagian dari spektrum elektromagnetik yang hanya terletak diluar sisi infrared cahaya tampak.
Wilayah radio frekuensi terletak sekitar 9 Hz-300 GHz dalam spectrum elektromagnetik seperti yang terlihat pada Gambar 1. Radiasi elektromagnetik meliputi panjang gelombang $(\lambda)$, frekuensi, dan energi foton (E).

Maxwell mendefenisikan gelombang elektromagnetik merupakan perpaduan gelombang listrik dan gelombang magnet yang merambat saling tegak lurus. Sifatini juga menyatakan bahwa gelombang 
elektromagnetik adalah gelombang transversal.

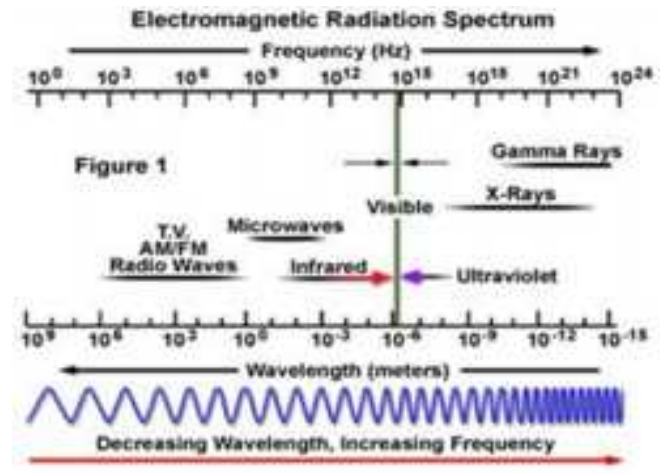

Gambar 1. Spektrum elektromagnetik [1].

Secara sistematik telah disusun persamaan Maxwell untuk menentukan perambatan gelombang elektromagnetik yang dinyatakan sebagai berikut:

$$
\begin{aligned}
& \nabla^{2} \boldsymbol{E}=\mu \mathrm{o} € \mathrm{o} \frac{\partial^{2} E}{\partial L^{2}} \\
& \nabla^{2} \boldsymbol{B}=\mu \mathrm{o} € \mathrm{o} \frac{\partial^{2} \boldsymbol{B}}{\partial L^{2}}
\end{aligned}
$$

Akibat adanya medan magnet $\mathrm{Bx}$ dan medan listrik Ex maka gaya dari radiasi frekuensi radio berpindah dari partikel kejaringan makromolekul (protein) yang mempengaruhi gaya listrik sebesar $\mathrm{Fx}=\mathrm{qEx}$

Dalam satuan m.k.s tensor dari medan elektromagnetik mengikuti persamaan:

$$
\begin{aligned}
& E x^{\prime}=\gamma(E x-v B y) \\
& B x^{\prime}=\gamma\left(B x+v / C^{\wedge} 2 E y\right) \\
& E y^{\prime}=\gamma(E y+v B x) \\
& B y^{\prime}=\gamma\left(B y-v / C^{\wedge} 2 E x\right) \\
& E z^{\prime}=E z \\
& B z^{\prime}=B z
\end{aligned}
$$

MRI merupakan suatu alat diagnostic mutakhir untuk memeriksa dan mendeteksi tubuh dengan menggunakan medan magnet yang besar dan gelombang frekuensi radio, tanpa operasi, penggunaan sinar $\mathrm{X}$, ataupun bahan radioaktif. Selama pemeriksan MRI akan memungkinkan molekul-molekul dalam tubuh bergerak dan bergabung untuk membentuk sinyal-sinyal. Sinyal ini akan ditangkap oleh antenna dan dikirimkan ke komputer untuk diproses dan ditampilkan di layar monitor menjadi sebuah gambaran yang jelas dari struktur rongga tubuh bagian dalam.

Komputer pada MRI merupakan otak dan komponen utama yang digunakan untuk memproses sinyal, menyimpan data dan menampilkan gambar yang dihasilkan. Selain sistem komputer komponen utama pada pesawat MRI adalah: pembangkit magnet utama, koil gradien, koil penyelaras (shim's coils), antenna atau koil pemancar dan penerima, serta sistem akuisisi data dalam komputer Seperti yang terlihat pada Gambar 2.

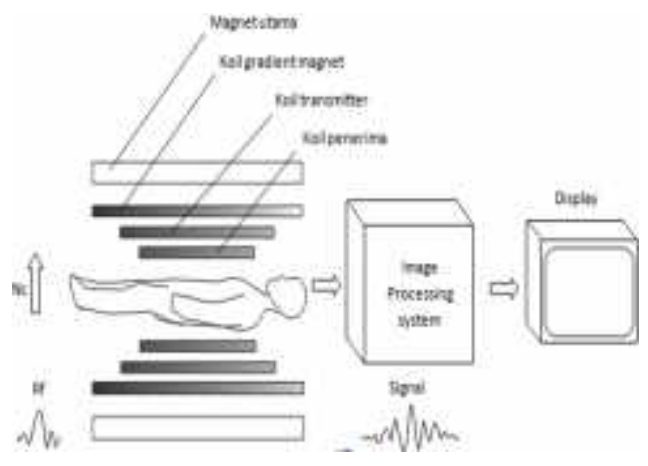

Gambar 2.Komponen mesin MRI [2].

\section{METODE PENELITIAN}

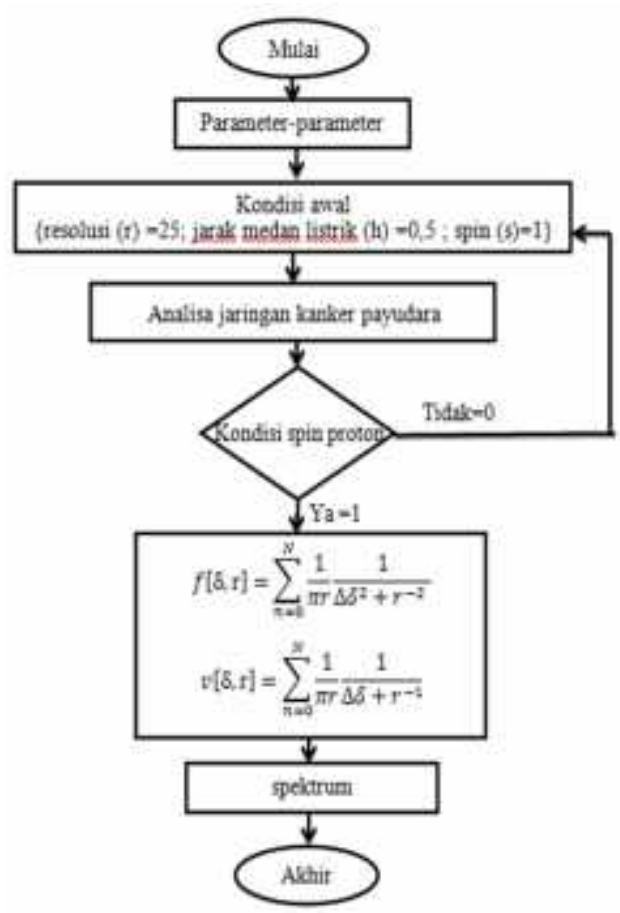

Gambar 3. Flowchart simulasi 
Metode penelitian menggunakan studi literature dengan metode komputasi wolfram matematika 9. Dengan diagram alir pemograman seperti Gambar 3.

\section{HASIL DAN PEMBAHASAN}

Penelitian ini memperoleh hasil berupa spectrum jaringan kanker payudara. Proses perhitungan pada penelitian meliputi parameter medan listrik dan medan magnet dengan melakukan simulasi dan permodelan menggunakan komputer dan perangkat lunak matematika 9 .

\section{Pengaruh Gaya pada Spektrum MRI untuk Variasi Resolusi}

Telah dilakukan penelitian terhadap nilai resolusi pada spektrum MRI dengan kategori

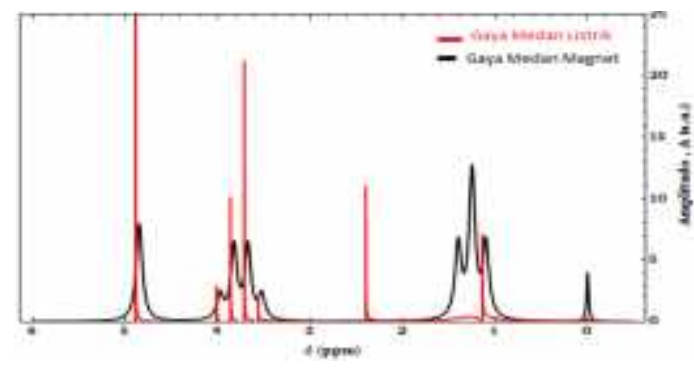

a nilai maksimum, nilai tengah dan minimum. Hasil Gambar 4.1 memperlihatkan pengaruh gaya medan listrik dan medan magnet untuk variasi resolusi 25, 16, dan 7 dengan jarak 0.5. Pengaruh tersebut dilihat dari hubungan amplitude terhadap nilai konsentrasinya (ppm).

Gambar 4.a resolusi maksimum $(\mathrm{r}=25)$ menghasilkan puncak spectrum gaya medan listrik yang tertinggi pada $5 \mathrm{ppm}$ dan amplitudo 25 a.u. Gambar 4.1 b resolusi nilai tengah $(\mathrm{r}=16)$ menghasilkan puncak medan listrik dikonsentrasi 3-4 ppm dan amplitudo 25 a.u. Resolusi minimum ( $\mathrm{r}=7$ ) menghasilkan empat puncak spectrum pada medan listrik dengan besar amplitude 25 a.u yaitu berada di antara konsentrasi 1-2 ppm, 2-3 ppm, 3-4 ppm dan 4 ppm terlihat pada Gambar $4.1 \mathrm{c}$.

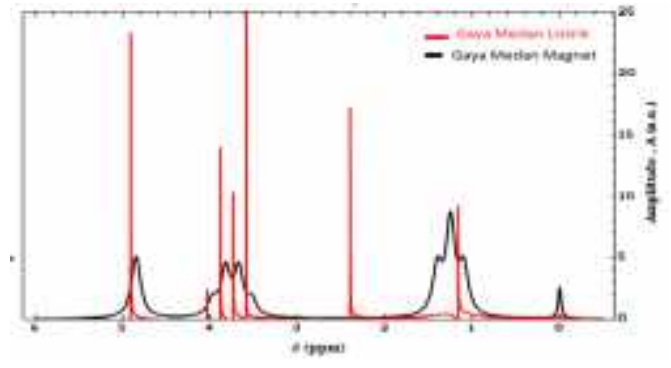

b

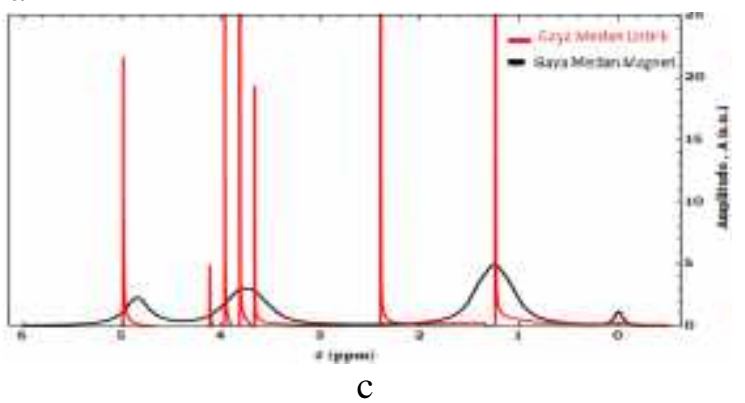

Gambar 4. Spektrum MRI jaringan kanker payudara dengan jarak 0.5 dan variasi resolusi yang digunakan a) $r=25$; b) $r=16$; c) $r=7$

Berdasarkan hasil yang didapat bahwa terjadinya pengaruh pada medan listrik disebabkan oleh jarak muatan antar proton terhadap resolusi. Semakin diperkecil resolusi maka jumlah pixel yang dihasilkan sinyal atau image akan semakin besar dan jarak muatan antar proton semakin jauh sehingga spektrum dihasilkan kurang bagus. Hal ini membuktikan bahwa semakin padat keberadaan proton didalam suatu jaringan, maka akan menghasilkan sinyal atau image yang bagus karena semakin banyak sinyal yang dipancarkan dari daerah jaringan tersebut.

\section{Spektrum MRI untuk variasi jarak medan listrik}

Berikut merupakan spektrum MRI untuk varaisi parameter jarak berdasarkan kategori maksimum, nilai tengah dan minimum dengan menggunakan nilai resolusi 25. Hasil dari variasi jarak tersebut dapat dilihat seperti pada 
Gambar 5. Semakin di perkecil jarak medan elektriknya (h) maka spectrum medan magnet

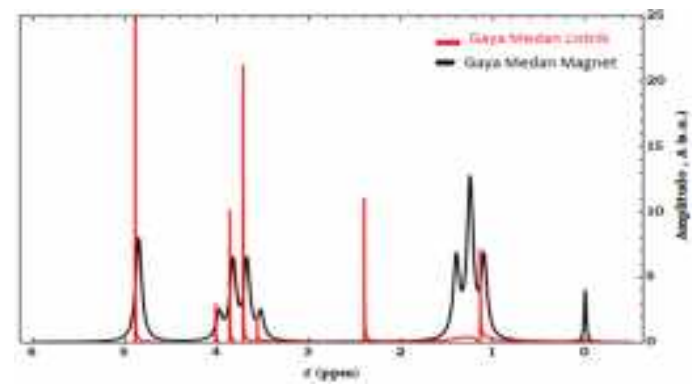

a dan medan listrik tersebut bergerak mendekati spin 1 (Gambar 5c).

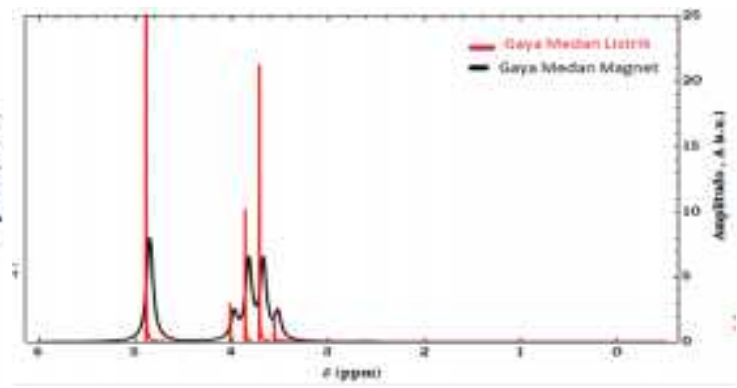

b

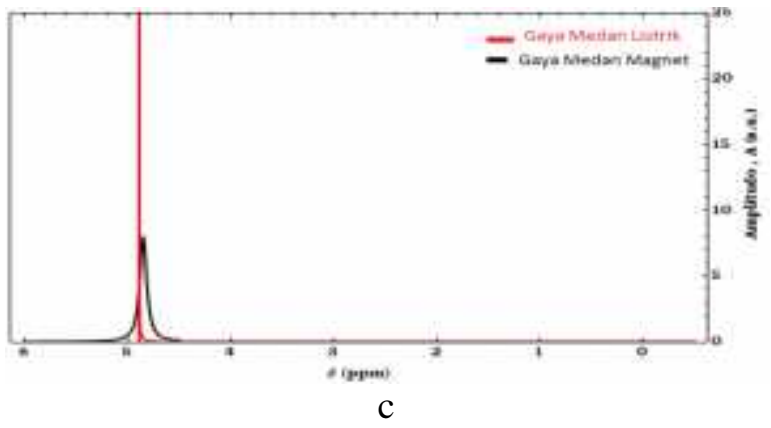

Gambar 5. Spektrum MRI jaringan kanker payudara dengan resolusi (r) 25 dan variasi jarak yang digunakan a) $\mathrm{h}=0.5 ; \mathrm{b}) \mathrm{h}=-2.5$; c) $\mathrm{h}=-4.5$.

\section{KESIMPULAN}

Berdasarkan pemodelan yang telah dilakukan maka resolusi maksimum $(\mathrm{r}=25)$ pada spectrum medan listrik menghasilkan 1 puncak yaitu berada dikonsentrasi 5 ppm dan besar amplitude 25 a.u. Resolusi medium $(\mathrm{r}=16)$ menghasilkan 1 puncak spectrum gaya medan listrik berada dikonsentrasi 3-4 ppm dan besar amplitude 25 a.u. Resolusi minimum ( $\mathrm{r}=7$ ) menghasilkan 4 puncak pada spectrum gaya medan listrik yaitu berada diantara 1-2 ppm, 2-3 ppm, 3-4 ppm dan 4 ppm dengan masing-masing amplitudo 25 a.u. Hasil spektrum MRI untuk variasi parameter jarak berbeda dengan variasi resolusi. Semakin diperkecil jarak medan listrik (h) maka spectrum untuk gaya medan magnet tersebut bergerak mendekati spin 1 .

\section{DAFTAR PUSTAKA}

1. Pierre, L. (1998). Observational Astrophysics. Springer-Verlag. Francois Lebrun: Francois Mignard.

2. Blink, E. J. (2004). Basic MRI Physics. ofor Anyone Who Does Not Have a Degree in Physics. Application Specialist. 